\title{
DUKUNGAN PASANGAN PADA PASIEN KANKER PAYUDARA YANG MENJALANI KEMOTERAPI DI RSI SULTAN AGUNG SEMARANG
}

\author{
Tri Nurhidayati ${ }^{1}$, Desi Ariyana Rahayu ${ }^{2}$ \\ 1,2 Fakultas IImu Keperawatan dan Kesehatan Universitas Muhammadiyah Semarang \\ email: tnh@unimus.ac.id
}

\begin{abstract}
Breast cancer is a disease than can afflect anyone, especially in women, and any type of treatment of breast disease can cause physiological, phychological and social problems in women. Body image can change due to psychological response for breast cancer patients. This study aims to determine the support of couples in breast cancer who get chemotherapy. The design of this research was qualitative using descriptive phneomenology. The finding of this research was couples support intrumental,award, emotional, and information. Suggestion their couples provided information actively and asked nurse or doctor during chemoterapy
\end{abstract}

Keywords: Breast cancer, chemotherapy, couple support

\section{ABSTRAK}

Kanker payudara merupakan penyakit yang dapat menyerang siapa saja, khususnya perempuan. Setiap jenis pengobatan penyakit tersebut dapat menyebabkan masalah fisiologis, psikologis, dan sosial. Pasien dapat mengalami perubahan citra tubuh karena respon psikologis. Penelitian ini bertujuan menentukan dukungan pasangan pada perempuan dengan kanker payudara yang menjalani kemoterapi. Penelitian ini merupakan penelitian kualitatif dengan desain fenomenologi deskriptif. Hasil penelitian menemukan bentuk dukungan pasangan berupa dukungan instrumental, penghargaan, emosional, dan informasi

Kata kunci: kanker payudara, kemoterapi, dukungan pasangan.

\section{PENDAHULUAN}

Kanker payudara merupakan penyakit yang dapat menyerang siapa saja, terutama pada wanita. Setiap jenis pengobatan terhadap penyakit ini dapat menimbulkan masalah fisiologis, psikologis dan social. Perubahan citra tubuh akibat perubahan fisik yang disertai pengobatan menjadi respon psikologis yang amat menekan bagi penderita kanker payudara. Kanker payudara telah membuat para penderitanya mengalami kecemasan terhadap proses pengobatan yang akan dijalaninya, sehingga mempengaruhi konsep diri yang pada akhirnya dapat mempengaruhi hubungan interpersonal pasien, termasuk pada pasangan hidupnya (Nuracmah, 2005).

Penyakit kanker di Indonesia menjadi penyebab kematian nomor 7 $(5,7 \%)$ setelah penyakit stroke, TB, hipertensi, cedera, perinatal dan DM (Riskesdas, 2007 dalam Depkes, 2009). Insiden kanker belum dapat diidentifikasi secara nasional, karena belum terdapat registrasi kanker secara nasional. Akan tetapi, dari beberapa pusat registrasi kanker di Indonesia terdapat sebanyak 
23.310 kejadian kanker payudara sebanyak 2.743 pasien.

Kasus penyakit kanker yang ditemukan di Provinsi Jawa Tengah pada tahun 2011 sebanyak 19.637 kasus meningkat bila dibandingkan dengan tahun 2010 sebanyak 13.277 kasus. Jumlah tersebut terdiri dari kanker servik 6.899 kasus $(35,13 \%)$, kanker payudara 9.542 kasus $(48,59 \%)$, kanker hepar $2.242(11,42 \%)$, dan kanker paru 954 kasus $(4,86 \%)$ (Dinas Kesehatan Propinsi Jawa Tengah, 2014).

Data di RSI Sultan Agung Semarang, pada tahun 2011 ada 355 pasien kanker, sedangkan tahun 2012 ada 358 pasien dan mengalami peningkatan pada tahun 2013 menjadi 468 pasien. Sedangkan pada bulan Januari - Oktober 2014 ada 322 pasien. Data pasien yang rawat jalan pada tahun 2011 ada 987 pasien, kemudian meningkat pada tahun 2012 sebanyak 1137 pasien sedangkan pada januariapril 2013 ada 441 pasien.

Banyak usaha yang dilakukan oleh pasien kanker payudara untuk melakukan pengobatan mulai dari pengangkatan payudara, radiasi, kemoterapi sampai imunoterapi. Namun, berbagai jenis pengobatan tersebut belum tentu dapat sembuh total jika kanker yang diderita sudah stadium akhir (Maydiana, 2009).

Menurut Wijayanti, (2007) bahwa pengobatan seperti operasi, dan kemoterapi dapat menimbulkan kondisi fisik yang sangat buruk yaitu mengalami kerontokan rambut dan kerja fisiologis dapat terganggu. Kondisi tersebut dapat menimbulkan rasa malu, cemas, dan penurunan harga diri. Selain itu jika hasil pengobatan yang tidak maksimal juga dapat menjadi stimulasi timbulnya kecemasan pasien.
Berbagai emosi yang telah dirasakan oleh klien, apabila sampai berlebihan dan berlangsung lama akan sangat mempengaruhi kesehatan wanita yang menderita penyakit kanker payudara. Maka dari itu kemampuan setiap individu dalam mengelola emosi sangatlah diperlukan agar perasaan klien dapat terungkap dengan baik (Goleman, 2007).

Peran serta keluarga dan orang di sekitarnya untuk memberikan dukungan hidup buat penderita kanker payudara akan sangat besar artinya. Keluarga harus merawat agar pasien tidak mengalami stres dan kemudian depresi akan penyakit yang dideritannya (Pamungkas, 2011). Penelitian Uliana (2015) menyebutkan pasien $\mathrm{Ca}$ payudara yang menjalani kemoterapi mengalami cemas berat $52.3 \%$.

Dukungan keluarga dalam hal ini pasangan sebagai suatu proses hubungan antara keluarga dengan lingkungan sosial. Jenis dukungan keluarga ada empat yaitu dukungan instrumental, informasional, penilaian, dan emosional. Dukungan emosional yaitu keluarga sebagai tempat yang aman dan damai untuk istirahat dan pemulihan serta membantu penguasaan terhadap emosi Friedman dalam Prasetyawati (2011).

Penelitian yang dilakukan Fajriati (2013) mengenai hubungan dukungan sosial dengan tingkat kecemasan pada pasien kanker yang akan menjalani kemoterapi di RS Roemani Semarang, mempunya hasil sebagian besar dukungan sosial adalah baik, serta ada hubungan antara dukungan sosial dengan tingkat kecemasan $(\rho=0,001)$. Penelitian yang di lakukan Subiatmi (2012) mengenai hubungan dukungan keluarga dan dukungan perawat dengan tingkat kecemasan pada pasien kanker 
yang menjalani kemoterapi di RSUP Dr Kariadi Semarang, hasil penelitian menunjukan bahwa dukungan keluarga dan perawat adalah sebagian besar baik, serta ada hubungan antara dukungan keluarga dan perawat dengan tingkat kecemasan $\quad(p=0,000)$. Penelitian Wahyono (2016) ada hubungan dukungan keluarga terhadap tingkat stress pasien $\mathrm{Ca}$ Payudara yang menjalani kemoterapi.

\section{METODE}

Penelitian ini adalah penelitian kualitatif menggunakan pendekatan fenomenologi deskriptif dengan melakukan eksplorasi langsung, menganalisis dan mendeskripsikan dukungan pasangan. Pengumpulan data dilakukan melalui in depth interview dan observasi langsung kepada partisipan. Proses penelitian fenomenologi deskriptif terdiri 3 tahap, yaitu intuiting, analyzing dan describing.

\section{HASIL DAN PEMBAHASAN}

Pada penelitian ini, diperoleh 9 penderita Ca Payudara dan 1 pasangan yang mendampingi saat kemoterapi. Subjek yang menjadi sampel adalah wanita berusia 35-55 tahun, pendidikan terakhir tidak sekolah-D3, 1 responden berasal dari Semarang dan 8 responden dari luar kota Semarang, seluruh responden menggunakan BPJS, dan diagnosa $\mathrm{Ca}$ mamae pasien beragam sejak 2012-2017. Semua responden tidak bekerja atau menjadi ibu rumah tangga.

Karakteristik responden berdasarkan jenis kelamin dimana jumlah responden wanita (100\%). Hal ini sesuai pendapat yang dikemukan Grace dan Borley (2007) bahwa perbandingan klien kanker payudara antara pria dan wanita yaitu 1:100. hal ini berkaitan dengan anatomi dan fisiologi payudara pria dan wanita. Rentang usia responden 39-53 tahun, dimana epidemiologi terjadinya kanker payudara adalah usia > 30 tahun. Pada usia ini terdapat perubahan hormonal karena melahirkan dalam usia 30 tahun lebih, menopause lambat dan terapi hormonal. Karakteristik pendidikan beragam menunjukkan semakin tinggi pendidikan, maka semakin tinggi kebutuhan untuk memperoleh kesehatan dan informasi perawatan. Pada responden ini semua menggunakan BPJS. Berkaitan dengan Undang-Undang Nomor 24 Tahun 2011 tentang Badan Penyelenggaraan Jaminan Sosial (UU BPJS), BPJS Kesehatan diselenggarakan secara nasional berdasarkan prinsip asuransi sosial dan prinsip ekuitas, dengan tujuan menjamin agar peserta memperoleh manfaat pemeliharaan kesehatan, dan perlindungan dalam memenuhi kebutuhan dasar kesehatan (http://www.jamsosindonesia. com) Menurut Bomar (2004), dukungan sosial merupakan bentuk perilaku melayani yang dilakukan oleh keluarga dan kerabat, baik dalam dukungan emosional (perhatian, kasih sayang, empati), dukungan penghargaan (menghargai, umpan balik), dukungan informasi (saran, nasihat, informasi) maupun dalam bentuk dukungan instrumental (bantuan dana, tenaga, dan waktu). Subjek yang menerima dukungan akan membuat pasien merasa nyaman, diperhatikan, dan tidak sendirian melakukan kemoterapi. Dukungan berupa semangat yang diberikan oleh keluarga subjek dan lingkungan disekitar subjek terutama pasangan atau suami. Suami adalah orang yang paling dekat dengan istri didalam sebuah keluarga yang senantiasa memberikan nasehat, saran, 
maupun pemberian informasi tentang kesehatan pasien yang diperoleh dari petugas kesehatan (Friedman, 2013). Dari hasil wawancara dan observasi yang ditemukan didapatkan 4 kategori dukungan pasangan yaitu:

a. Dukungan Instrumental

Dukungan instrumental yang didapatkan dalam kelima pasangan yaitu mendukung finansial, membantu mengambilkan makanan dan minuman, mengantar kemoterapi, memberikan fasilitas hiburan baik berupa musik dan mengobrol, serta mengingatkan jadwal kemoterapi. Keluarga selalu mengantarkan dan menunggu saat menjalani terapi. Responden dari luar kota ada juga yang diantar rombongan keluarga, anaknya, karena keterbatasan suami.

"...kali ini saya diantar ponakan saya, kan suami saya kerja di Jakarta mbak, jadi pulangnya setiap 3 minggu sekali, kalau pas dirumah saya ya diantar" (R1)

"diantar terus mbak, kadang juga ada yang lain seperti adek, anak"(R4)

Hal ini dikuatkan dengan hasil penelitian Permatasari (2016) didapatkan perilaku dukungan instrumental berupa pemberian fasilitas pendukung kesehatan, bantuan dana, pendampingan dalam berobat, fleksibilitas peran, sikap selektif dalam mengatur pola makan, dan fleksibilitas waktu. Penelitian Puspitasari (2014) menegaskan bahwa dukungan instrumental yang diberikan cukup dengan mengantarkan dan menunggu saat menjalani terapi, menyarankan beristirahat, melayani dan membantu pasien ketika membutuhkan sesuatu serta memberikan sesuatu yang disukai pasien meski dengan harga tidak mahal.
Semua responden menggunakan akses pembayaran BPJS sehingga memudahkan memperoleh pelayanan kemoterapi dari segi pembiayaan, keluraga keberatan jika harus membayar terapi. Faktor ekonomi akan berpengaruh pada dukungan kelurga yang berpenghasilan tidak menentu akan mengurangi tingkat dukungan terhadap pasien yang menjalani terapi. Kondisi ekonomi mempengaruhi kemampuan orang untuk berobat maupun dalam hal perawatan. Penderita dengan ekonomi yang rendah akan tidak teratur dalam proses pengobatan (Papastavrou, Charalambous, Tsangari, 2009).

\section{b. Dukungan penghargaan}

Dukungan penghargaan yang didapatkan dalam penelitian yaitu pasangan peduli dengan pengobatan.

"...iya mbak, justru bapak yang mendukung kemoterapi.." (R7)

"..iya mbak, waktu pertama kali saya kena kanker payudara kan saya langsung drop mbak, kan saya habis lihat hasil PA nya disini, pikiran saya sudah macam-macam itu mbak, lalu kami sama-sama mencari tahu tentang kanker payudara lewat internet..." (R1)

Hal ini dikuatkan penelitian Permatasari (2016) yang menyebutkan perilaku dukungan penghargaan yaitu pemberian pujian, motivasi dan semangat pada pasangan dalam hal ini yaitu proses pengobatan. Penelitian Pitasari (2014) dukungan penghargaan sebagian besar baik $(54,8 \%)$. Menurut Friedman (2013), keluarga memberikan dukungan untuk kesembuhan pasien, tidak memaksakan apa yang tidak dikehendaki pasien, penghargaan atas usaha yang dilakukan pasien, memberikan umpan balik mengenai hasil 
prestasinya akan memperkuat kepercayaan serta harga diri individu tersebut. Sehingga kualitas hidup pasien meningkat (Henriksson \& Arestedt, 2013).

c. Dukungan emosional

Dukungan emosi yang didapatkan dalam hasil penelitian yaitu pasangan memberi semangat, dorongan, dan motivasi selama proses jalannya kemoterapi.

" ...meskipun jauh selalu diberi semangat mbak lewat WA, SMS, tellepon, kadang video call.." (R1)

"...kadang-kadang menasehati mbak, menghibur dan kadangkadang sering menggodain mbak seperti pacaran, lah kadang-kadang anak-anak sama cucu itu suka bilang kalau mbak kakung sama mbah putri pacaran, terus anak dan menantu ya tertawa semau.."(R5)

Hal ini sejalan dengan pendapat Sarafino (2004) yang menyatakan bahwa dukungan emosi melibatkan ekspresi, rasa empati, dan perhatian terhadap seseorang sehingga membuat penderita kanker payudara merasa lebih baik, memperoleh keyakinannya, merasa dimiliki dan dicintai. Hal ini dikuatkan pendapat Cohen dan Sync (1985) bahwa dukungan sosial dapat diperoleh dari orang yang dipercaya. Hal ini juga sejalan dengan penelitian Permatasari (2016) yang menemukan dukungan emosional diwujudkan dalam perilaku merasa dimiliki, dicintai, membangun keyakinan untuk sembuh, peningkatan komunikasi dengan pasangan, penerimaan oleh pasangan, sikap empati dan peduli, kepercayaan pada pasangan, rasa pengertian pada pasangan dan menunjukkan kasih sayang. Penelitian Pitasari (2014) memberikan dukungan emosional cukup $(87,1 \%)$, padahal dukungan emosional amat penting dan bisa berupa empati, cinta dan kejujuran, serta mendengarkan semua keluhan klien tentang pengobatan yang dijalani mampu mengurangi beban yang pasien rasakan (Grant, Sun, Fujinami, Sidhu, Otis, Juarez, et al, 2013)

d. Dukungan informasi

Dukungan informasi yang didapatkan dalam hasil penelitian pasangan yang tidak aktif bertanya bahkan takut dengan kondisi istrinya, serta tidak memberikan fasilitas bacaan yang mendukung.

"...ndak mbak, malah nggak
paham ..."(R2)
"...kadang malah ponakan yang tanya...(R4)

"..tidak mbak soalnya bapak takut malahan, malah saya sendiri yang tanya.."(R5)

Namun ada juga pasangan yang aktif mau bertanya kepada dokternya, yang lain bertanya melalui saudara maupun anaknya.

"Saya suka tanya-tanya. Saya tanya-tanya makanan apa yang perlu dimakan gitu mbak" (R10)

Hal ini sejalan dengan penelitian Nurdjanah (2015) menyebutkan dukungan yang paling sedikit yaitu dukungan informasional sebanyak $11,08 \%$ dari 35 responden. Dukungan informasional adalah pemberian informasi terkait hal yang dibutuhkan responden. Sistem dukungan informasional mengenai individu yang sakit dikarenakan karakteristik pendidikan beragam. Semakin pendidikan tinggi maka keinginan mencari tahu juga tinggi, pada pendidikan yang rendah berasal dari luar daerah dan kesulitan mencari informasi melalui majalah, internet, maupun diskusi dengan orang yang dengan penyakit sama (Widyanto, 2014). Hal 
yang berbeda Penelitian Pitasari (2014) yang menemukan dukungan informasional sebagian baik $(67,7 \%)$. Muliani (2010) mengatakan keyakinan dan tindakan seseorang terhadap kesehatan dipengaaruhi pengetahuan berbagai fungsi tubuh, penyakit, latar belakang pendidikan dan pengalaman masa lalu.

\section{Tabel 1. Bentuk Dukungan pasangan pada penderita Ca Payudara yang menjalani kemoterapi}

\begin{tabular}{|c|c|c|}
\hline No & Dukungan & Indikator Perilaku \\
\hline 1 & Instrumental & $\begin{array}{l}\text { Menanggung pemeriksaan } \\
\text { kesehatan, } \\
\text { bantuan saat kesulitan } \\
\text { beraktivitas, Mengantar } \\
\text { saat kemoterapi, Memberi } \\
\text { fasilitas hiburan saat } \\
\text { kemoterapi, Memenuhi } \\
\text { kebutuhan makan dan } \\
\text { minuman }\end{array}$ \\
\hline 2 & Penghargaan & $\begin{array}{lr}\text { Peduli dengan proses } \\
\text { pengobatan kemoterapi, } \\
\text { mengingatkan } \\
\text { kemoterapi }\end{array}$ \\
\hline 3 & Emosional & $\begin{array}{l}\text { Menghibur, } \\
\text { Menerima, } \\
\text { pasangan }\end{array}$ \\
\hline 4 & Informasi & $\begin{array}{l}\text { Aktif bertanya pada } \\
\text { petugas kesehatan, } \\
\text { Memberi buku, mencari } \\
\text { tahu melalui internet, } \\
\text { Memberi saran, nasihat }\end{array}$ \\
\hline
\end{tabular}

\section{KESIMPULAN DAN SARAN}

Terdapat berbagai macam bentuk dukungan yang diberikan suami kepada pasangannya yang sedang menjalani kemoterapi yaitu dukungan emosional dengan memberi semangat dan pujian saat kemoterapi, dorongan, menghibur serta memotivasi pasien menjalani pengobatan, dukungan penilaian dengan peduli pengobatan dan membiarkan pasien yakin dengan proses kemoterapi, dukungan instrumental dengan menanggung biaya pemeriksaan, memberi bantuan saat beraktivitas, mengantar saat kemoterapi, memberi fasilitas hiburan, serta memenuhi kebutuhan makan dan minum, dan dukungan informasi dengan memberi fasilitas buku, mencari di internet, aktif bertanya pada dokter. Berdasarkan hasil penelitian yang sudah dilakukan , maka peneliti memberi saran pertama bagi pasangan untuk memberikan dukungan untuk mengoptimalkan proses kemoterapi, bisa memperluas pengetahuan tentang kanker dan kemoterapi.

\section{UCAPAN TERIMAKASIH}

Peneliti mengucapkan terima kasih kepada berbagai pihak khususnya Ristekdikti sebagai penyandang dana dan LPPM Unimus beserta jajarannya dalam membantu menyelesaikan penelitian ini.

\section{DAFTAR PUSTAKA}

Depkes RI. (2014). Profil Kesehatan Indonesia Tahun 2013 http://www.depkes.go.id/downloa d.php?file=download/pusdatin/pr ofil-kesehatan-indonesia/profilkesehatan-indonesia-2013.pdf. Diunduh 16 oktober 2014.

Dinas Kesehatan Provinsi Jawa Tengah. (2014). Profil Kesehatan Provinsi Jawa Tengah Tahun 2013.http://www.dinkesjatengpro v.go.id/v2014/Document/profil20 13/Diunduh 11 november 2014.

Fajriati, A. (2013). Hubungan Dukungan Sosial Dengan Tingkat Kecemasan Pada Pasien Kanker Yang Akan Menjalani Kemoterapi di RS Roemani Semarang. http://digilib.unimus.ac.id

Friedman, M.M. (2013). Buku ajar 
keperawatan keluarga: Riset, teori dan praktik. Edisi 5, Jakarta: EGC

Goleman. (2007). Emotional intelligence. Jakarta: Gramedia Pustaka Utama

Grant, M., Sun, V., Fujinami, R. Sidhu, R. Otis Green, S, Juarez, G., et al (2013). Family care giver burden, skills preparedness, and quality of life in nonsmall cell lung cancer, Oncol Nurs Forum: 337346.

Mardiana, L. (2007). Kanker pada wanita; pencegahan dan pengobatan dengan tanaman obat. Cetakan V. Jakarta: Penebar Swadaya.

Nurachmah, E. (2005). Dampak kanker payudara dan pengobatannya terhadap Aspek Bio-psiko-sosiospiritual klien yang berpartisipasi dalam kelompok pendukung. Jurnal Keperawatan Indonesia, Vol. II: hal 186-194.

Nurdjanah, S, (2015). Hubungan dukungan keluarga dan kepatuhan pelaksanaan Program kemoterapi di RSUP Dr Sarjito Yogyakarta,

Pamungkas, Z. (2011). Deteksi dini kanker payudara. Jogjakarta: Buku Biru.

Papastavrou, E, Charalambous, A. Tsangari $H$. (2009). Exploring the other side of cancer care: the informal caregiver, Eur $\mathrm{J}$ Oncol Nurs:36-128

Permatasari, I. (2016). Dukungan suami pada istri dalam menjalani pengobatan Pasca Operasi kanker Payudara,

Prasetyawati, A. (2011). IImu kesehatan masyarakat untuk kebidanan holistik. Yogyakarta: Nuha medika.

Safaria. T, \& Saputra, N. E. 2009. Manajemen Emosi: sebuah panduan cerdas Bagaimana Mengelola Emosi positif dalam Hidup Anda. Jakarta: Bumi Aksara.

Subiatmi. (2012). Hubungan Dukungan Keluarga dan Dukungan Perawat dengan Tingkat Kecemasan pada Pasien Kanker yang Menjalani Kemoterapi di RSUP Dr Kariadi Semarang. http://digilib.unimus.ac.id

Uliana, U., 2015. Tingkat kecemasan pada pasien kanker payudara saat dilakukan kemoterapi di RSI Sultan Agung, Skripsi, Tidak diterbitkan

Wahyono, 2015. Dukungan Keluarga terhadap tingkat stres pasien kanker payudara yang menjalani kemoterapi di RSI Sultan Agung, Skripsi.Tidak diterbitkan 